\title{
Plasmodium falciparum malaria and invasive bacterial co-infection in young African children: the dysfunctional spleen hypothesis
}

\author{
Gloria P Gómez-Pérez ${ }^{1,2^{*}}$, Robin van Bruggen ${ }^{3}$, Martin P Grobusch² and Carlota Dobaño ${ }^{1}$
}

\begin{abstract}
Children with recent or acute malaria episodes are at increased risk of invasive bacterial infections (IBI). However, the exact nature of the malaria-IBI association is still unclear. Young children have an age-related spleen immunologic immaturity, mainly due to the still ongoing development of the marginal zone (MZ) B cell subset. By mounting a rapid antibody response against encapsulated bacteria, these cells are critical for the defence against highly pathogenic microorganisms that do not elicit classical T cell-dependent responses. There is increasing evidence that the anatomy of the spleen becomes disorganized during malaria infection, with complete dissolution of the $M Z$ and apoptosis of $M Z B$ cells. Correspondingly, a reduction in the frequency of the peripheral equivalent of the $M Z B$ cells has been found in malaria endemic areas. A remarkable similarity exists in IBI susceptibility between African children with malaria and hyposplenic or splenectomized patients. However, studies specifically assessing the immune function of the spleen in controlling bacterial infections in young children with malaria are scarce.

Here, it is hypothesized that Plasmodium falciparum malaria infection constitutes a detrimental factor in the still immature spleen function of young children, resulting in a factually hyposplenic state during malaria episodes, putting children with malaria at a high risk to develop life-threatening bacterial infections. Studies to confirm or reject this hypothesis are greatly needed, as well as the development of affordable and feasible tools to assess the immune spleen function against encapsulated bacteria in children with malaria.
\end{abstract}

Keywords: Plasmodium, Malaria, Invasive bacterial infection, Children, Marginal zone B cells, Hyposplenism, Spleen

\section{Background}

For years, in malaria-endemic settings the percentage of children with splenomegaly has been correlated with intensity of malaria transmission in a community. The method to evaluate malaria endemicity by spleen measurement is named the Hackett score, and it was introduced by Dempster in India in 1848 before it was known that Plasmodium species were the causative agent of malaria. Later, this method became accepted by the World Health Organization to be used in malaria surveys [1,2].

The spleen is a complex lymphoid organ with several important functions that starts its development in foetal

\footnotetext{
* Correspondence: patricia.gomez@cresib.cat

1 Barcelona Centre for International Health Research (CRESIB, Hospital Clínic-Universitat de Barcelona), Barcelona 08036, Spain

${ }^{2}$ Centre of Tropical Medicine and Travel Medicine, Department of Infectious Diseases, Academic Medical Centre, University of Amsterdam, Meibergdreef 9, PO Box 22660, 1100 DD Amsterdam, The Netherlands

Full list of author information is available at the end of the article
}

life and reaches full maturation during early childhood, around age two to three years [3-5]. The characteristic that makes this organ unique is that it is the only lymphoid organ specialized in the filtration of blood, while the rest of lymphoid organs filter lymph. Additionally, the spleen contains the largest single aggregate of lymphoid tissue in the body, housing approximately one third of the total circulating lymphocytes, thus with a vast number of them migrating through the spleen at any given time, surpassing the combined traffic of all lymph nodes in the body [6]. It is also in the spleen where a large population of naïve $B$ cells produced in the bone marrow matures into memory B cells. Overall, a special attribute of the spleen immune function is its capacity to mount $\mathrm{T}$ cell-independent (TI) immune responses against polysaccharide and lipopolysaccharide micro-organism antigens in non-immune individuals (TI-1 and TI-2 responses, respectively). This response can take place within 24 to 
72 hours after encountering bacteria or other pathogens by phagocytosis and readily production of IgM [6-8]. Hence, the spleen function 'fills in' the time gap between the innate and the adaptive immune response, with the latter taking several days to develop. The filtration of bacteria and their destruction in the spleen must be a rapid process in order to overcome the speed of replication of these micro-organisms [6], a process for which the spleen is fully equipped and in which absence, lifethreatening invasive bacterial infections (IBI) can enfold. Therefore, the spleen represents the second line of protection against microbes when they manage to breach the first line of protection, the mucosal barrier [9]. The unique structure of the microvascular pathways of the spleen (Figure 1) reflects its two most important functions: (1) the removal of senescent and damaged red blood cells (RBCs); and, (2) the removal of blood-borne microorganisms and cellular debris [10-12]. Both functions involve an intense phagocytic activity that occurs in different compartments of this organ by different sets of immune cells.

To accomplish its functions, the spleen encompasses the following anatomic subunits (Figure 1): (1) the white pulp (WP), containing $\mathrm{T}$ cell zones (periarteriolar lymphoid sheath (PALS)) and B cell follicles, where the adaptive immune response takes place; (2) the marginal zone (MZ) containing macrophages, dendritic cells (DCs), natural killer $\mathrm{T}$ (NKT) cells (in mice), B cell-helper neutrophils $\left(\mathrm{N}_{\mathrm{BH}}\right)$, innate lymphoid cells type 3 (ILC3), CD4 $4^{+}$ T lymphocytes, MZ B cells and memory B cells, where TI-1 and TI-2 responses take place; (3) the perifollicular zone $(\mathrm{PFz})$, separating the $\mathrm{MZ}$ from the red pulp (RP) and containing RBCs, pericapillary macrophages, $\mathrm{N}_{\mathrm{BH}}$, and ILC3; (4) the RP-containing macrophages, DCs, $\mathrm{N}_{\mathrm{BH}}$, plasmablasts, being the place where RBCs are efficiently filtered from the circulation and where reticulocytes mature $[9,10,13-16]$. Five to six per cent of the cardiac output of 5-6 L per minute in adults flows through the

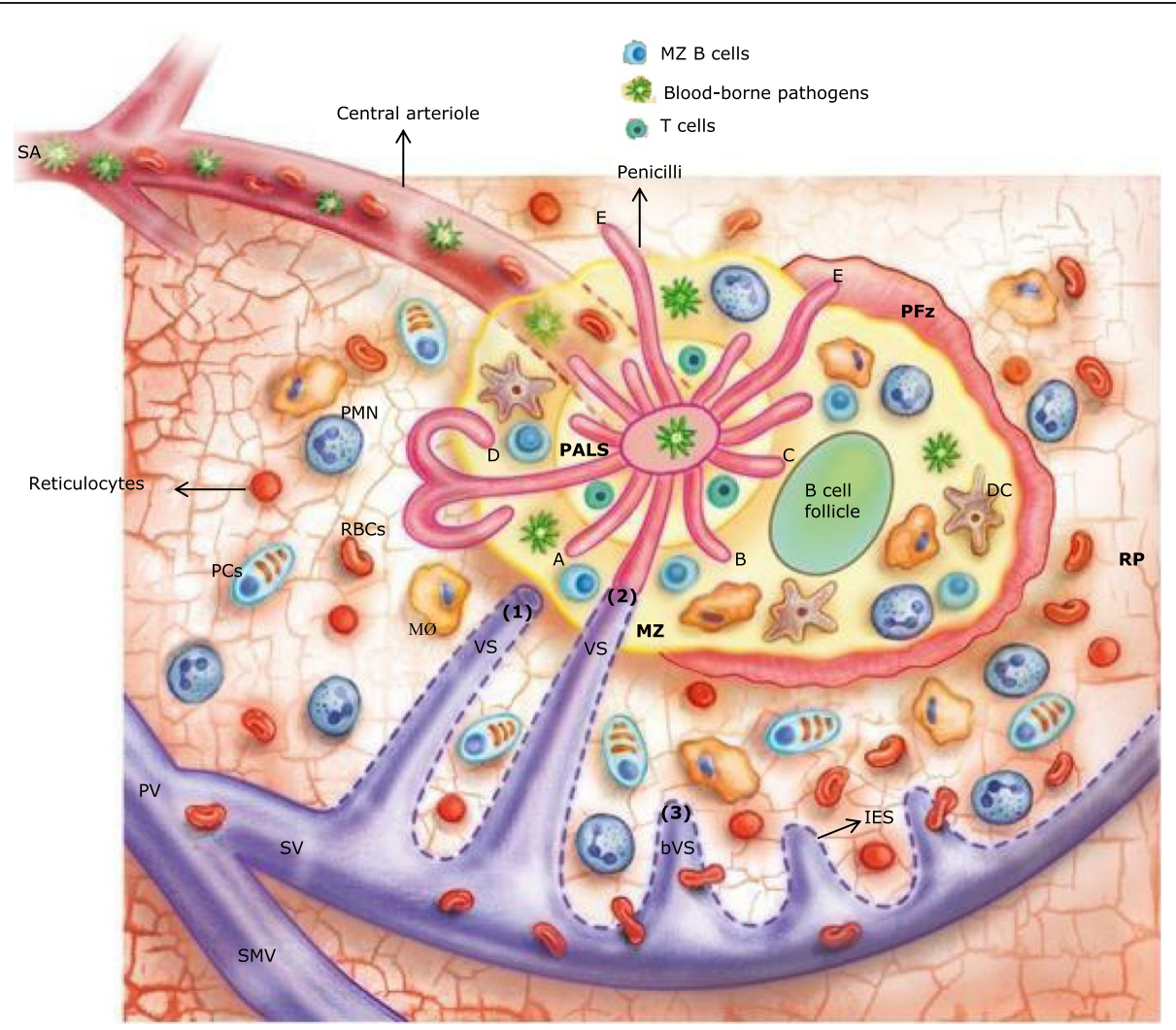

Figure 1 Structure of the human spleen. Adapted from Bowdler [6]. Arterial blood enters the spleen through the splenic artery (SA) that branches in multiple arterioles. Central arterioles are surrounded by periarteriolar lymphoid sheaths (PALS) that contain the T cell zone. Next to the PALS are the B cell follicles. Together, PALS and B cell follicles constitute the white pulp of the spleen (WP). Most of the arterial blood that enters the spleen is drained into the marginal zone (MZ) through small open ended capillaries named penicilli. Ninety per cent of the blood that enter the MZ is drained directly into (1) open ended venous sinuses (VS) or (2) penicilli-VS connections, constituting the fast pathway. Ten per cent of the blood is drain into the open circulation of the perifollicular zone (PFz) and red pulp (RP) constituting the slow pathway. Normal red blood cells (RBC) need to pass into (3) blind-ended VS (bVS) through interendothelial slits (IES) to go back to the peripheral circulation, VS drain into the splenic vein (SV), and the latter into the portal vein (PV) after joining the superior mesenteric vein (SMV). PCs: plasma cells; PMN: polymorphonuclear neutrophils. 
spleen $[17,18]$. Most of the blood flow is deposited in the MZ through capillaries branched from splenic central arterioles (Figure 1). The small capillaries in the MZ called penicilli distribute part of the blood flow to the follicles, the PFz and the RP [6]. Penicilli have different possible ends (Figure 1): (A) and (B) the MZ at different points; $(C)$ penicilli can enter the $M Z$ and curved to end into the B cell follicle; (D) they could reach the RP and curve back to the external border of the MZ; (E) or they could drain directly into the PFz and the RP. Blood components, possibly containing foreign antigens, are sorted in the MZ by cell-cell interactions with the immune and endothelial cells located in this zone, to the WP or to the RP. Distribution of the blood cells is not random. Ninety per cent of the blood flow coming out from the $\mathrm{MZ}$ is drained directly into open ended venous sinuses (VS) or penicillin-VS connections, and from there to the splenic venous circulation constituting the fast pathway. Ten percent of the blood is drained into an open circulation system in the PFz and the RP (slow pathway) $[6,18]$. The RP is constituted by a reticular meshwork with pulp cords that form a three-dimensional web where specialized macrophages reside. Here, in the slow pathway, immature RBCs (reticulocytes) and abnormal RBCs adhere to the meshwork mediated by adhesion molecules, or are being captured by macrophages due to specific signals of immaturity, aging or damage, and no longer circulate. Blood-borne pathogens and debris can also be captured in the RP. Normal RBCs pass through the RP towards the inter-endothelial slits (IES) on the walls of the blindended VS located in this area, trespassing into the VS lumen and going back into the peripheral circulation (Figure 1). All this 'stickiness' slows down the speed of RBC flow into the VS, because even normal RBCs transiently adhere to the reticular meshwork, reaching the RP haematocrit concentrations as high as two-fold the arterial haematocrit ( $80 \%)$, representing $75 \%$ of the spleen volume in normal conditions [6]. Damaged senescent RBC can also be captured in the RP by mechanical retention. Nevertheless, the 90 to $10 \%$ differential distribution of the blood flow in the spleen to the lymphocyte-RBC compartments, respectively, suggest that the immunological function of the spleen takes priority over the filtration of blood cellular elements in the RP [6]. Importantly, all this extremely organized biophysical distribution of the blood and its cellular components into the different subunits of the spleen is disrupted in malaria infection $[17,19,20]$.

Plasmodium falciparum malaria causes alterations in the function of the cells of the innate immune system such as macrophages [21], neutrophils [22] and dendritic cells [23]. It also produces changes in the adaptive immune system, altering B cell populations [24-26] and the response to certain vaccines [27]. Regulatory cytokines released during acute infection aiming to control the pro-inflammatory response against malaria parasites [28] could impair the mucosal immune response to invasive non-typhoid salmonellae (NTS) infections [29]. Currently, there is increasing evidence in the scientific literature that young children (<three years old) infected with malaria might suffer from functional hyposplenism. Here, it is hypothesized that $P$. falciparum infection impairs the immunological response of the spleen against encapsulated bacteria in young children, a postulate built upon the following observations.

\section{Observation 1. Children with malaria are similar to splenectomized patients or patients with hyposplenism regarding their susceptibility to IBI}

One of the risk factors to develop IBI in Africa is P. falciparum malaria [30-33]. Bacteria responsible for these invasive infections in patients with malaria are NTS, Streptococcus pneumoniae, Haemophilus influenzae type b, Staphylococcus aureus, Escherichia coli and other gramnegative bacteria [30-32,34-37]. Reported specific risk factors to develop NTS bacteraemia are: younger age, acute and recent malaria infection, severe malarial anaemia (SMA), splenomegaly, human immunodeficiency virus (HIV) and severe malnutrition [32,33,36,38-44]. Therefore, it is well established that African infants younger than 36 months bear the brunt of malaria infection, presenting with the highest rates of IBI co-infection compared with older children and HIV-negative adults $[33,42,43]$. Remarkably, splenectomized patients or those with hyposplenic states are well known to be susceptible to develop serious IBI by this same group of bacteria [45-55]. For example, it is common knowledge that splenectomized patients are susceptible to overwhelming post-splenectomy infection syndrome (OPSI), which consists of a fulminant sepsis mainly caused by S. pneumoniae, characterized by a particularly high mortality [45]. Of note, among splenectomized patients, infants and young children are at higher risk for IBI than adults [54]. The reason is that young asplenic children have low pre-existing circulating antibodies and, in the absence of the spleen, are unable to mount a sufficiently fast antibody response against intravascular antigens and to phagocytose antibody un-opsonized bacteria while the adaptive immune response is under development [6]. Conversely, the splenectomized adult population tends to have pre-existing antibodies due to a larger immunological memory repertoire compared to very young children, overcoming the necessity for developing a fast immune response and controlling the infection. These immune complexes in the absence of the spleen can then be phagocytosed in the liver by Kupffer cells $[6,56]$, although less efficiently than in the spleen, explaining the occurrence of IBI also in adult splenectomized patients. A 
very well studied hyposplenic population is sickle cell disease (SCD) individuals [11,45,49,55,57-59]. Interestingly, as in the case of splenectomized children, infants and young children with SCD are at higher risk of IBI when compared to the adult population [57]. Children with SCD (homozygous genotype) under five years of age present IBI by S. pneumoniae at rates 30-100 times higher than those expected in healthy children from the same age group [58]. Splenic dysfunction is the foremost contributor to the enlarged risk.

\section{What are the underlying immunological mechanisms that make hyposplenic subjects, especially young children, susceptible to IBI? \\ Opsonization is impaired in the absence of spleen}

Routinely, hyposplenism has been diagnosed by haematological rather than immunological methods [6]. Nevertheless, Lammers et al. [11] have performed a study in SCD patients (homozygous (SS) and heterozygous (SC) genotype) and splenectomized patients, aiming at correlating the results of spleen haematological function tests with conventional methods, to the immunological spleen function and peripheral B cell subsets in these different hyposplenic individuals as compared to control subjects. The methods used to assess the haematological function of the spleen were (i) Howell Jolly bodies (HJB) assessment; (ii) pitted red cell count; and, (iii) ${ }^{99 \mathrm{~m}}$ Tc-labelled autologous RBC scintigraphy to measure functional splenic volumes (FSV). The immunological function was assessed by studying the response to polysaccharide vaccines. As expected, SS and SC individuals had a significantly diminished anti-polysaccharide response. Interestingly, HJB were indicative of splenic dysfunction; however, its absence did not necessarily indicate a normal functioning spleen tissue. Even more interesting, the FSV was strongly correlated with the amount of MZ B cells in peripheral circulation, being significantly reduced in SS and splenectomized patients, thus corroborating previous findings [60]. These results indicate that the MZ B cell subset population might be reduced in the spleen of hyposplenic individuals, with the consequently impaired immune response to encapsulated bacteria and reduced IgM response. These results are in correlation with the well-established functional opsonization failure in hyposplenic patients $[58,61,62]$. An illustration of this defective opsonization is found in a clinical case report of a patient with SCD who presented with refractory septic shock. Despite aggressive therapy, the patient remained on two vasopressors and yielded persistent bacteraemia. Within one day of starting intravenous g-globulin, vasopressors could be discontinued, indicating a quick response to the g-globulin infusion as a rescue therapy [63].

Additionally, in the spleen tuftsin is synthetized, an opsonin that activates the alternative complement pathway
$[6,17]$, and that has receptors expressed on monocytes/ macrophages, neutrophils and NK cells [64]. Upon binding its receptor, the complex is taken into the phagocyte and initiates the production of superoxide and nitroxide radicals, essential molecules for the killing of phagocytosed bacteria [64]. Therefore, the main outcome of tuftsin binding to macrophages and neutrophils is the stimulation of the ability of these cells to digest that leads to termination of phagocytosis in lymphoid formations [64]. Its importance has been confirmed by the development of fatal infections in splenectomized humans and other animals with lack of tuftsin [64]. Moreover, serum tuftsin concentrations are decreased in SCD subjects, causing a functional defect in the alternative complement pathway $[65,66]$. Importantly, tuftsin derivatives and analogues such as polytuftsin and rigin have been tested as therapeutic tools in several macrophage-based infections [67], showing to increase anti-tuberculosis drug treatment uptake by macrophages [68]. Tuftsin has also been used as a malaria and influenza A vaccine adjuvant [69-71], as a prophylactic in malaria animal models improving infection control [72], and as an immune-stimulating molecule along with antifungal agents in the treatment of opportunistic fungal infections [73]. In addition, combined anti-leishmanial drug treatment with tuftsin increases Leishmania parasite phagocytosis by macrophages [74], and when used as adjuvant treatment it helps to control sepsis in a murine model [75].

\section{Neutrophil and monocyte dysfunction}

Patients with malaria infection and SCD present with neutrophil dysfunction, characterized by defective locomotion, phagocytic processes and bactericidal performance $[22,66,76]$, related to a poor or almost absent oxidative activity in a subpopulation of neutrophils [66]. Additional studies show similar alterations in the monocyte subsets as well, related to haemolysis itself, but overall due to a direct toxic effect of iron liberated from malarial pigment (haemozoin) and through adhesion of infected RBC (iRBC) to monocytes, macrophages and myeloid DC surfaces [21,23,76,77]. Therefore, patients with SCD and malaria, as well as patients with other haemolytic diseases such as bartonellosis, are unusually susceptible to bloodstream invasion with Salmonella spp. [78]. In children with mostly (95\%) uncomplicated $P$. falciparum malaria, with ages between four and eight years, it was found that the neutrophil dysfunction was a consequence of induction of a haem-degrading enzyme (haem oxygenase-1) in neutrophil progenitors in the bone marrow [22]. The dysfunction in oxidative burst activity did not affect the whole neutrophil population and it was long-lasting, recovering normal function only eight weeks on average after a malaria episode. However, in this study it was not possible to establish the threshold of proportion 
of dysfunctional neutrophil population needed in blood in order to increase the susceptibility of malaria patients to NTS bacteraemia. Neither was it possible to explain why young children are more susceptible to NTS systemic infections than immune-competent adults, since neutrophil dysfunction due to falciparum malaria could also occur in the adult population during malaria episodes. As the phagocytosis by mononuclear cells and neutrophils is enhanced in the presence of antibodies, and in SCD patients bacterial phagocytosis is substantially improved with immunoglobulin (Ig) treatment [63], here it is proposed that neutrophil dysfunction may be contributing to the increased susceptibility to IBI in young children with malaria [22], but it is not the most important factor.

\section{Observation 2. MZ B cells are decreased in children with malaria}

As aforementioned, one of the anatomic subunits of the spleen tissue is the MZ. The MZ of the spleen is strategically positioned between the lymphoid compartment of the spleen, the WP, and the more innate, scavenging RP compartment (Figure 1). Most of the arterial blood that enters the spleen runs through the MZ inhabited by a special set of cells, such as macrophages expressing unique combinations of pattern recognition receptors, as well as MZ B cells that can be readily activated [19]. MZ $B$ cells are a distinct $B$ cell lineage [79] with a unique surface phenotype, expressing polyreactive IgM (B cell receptor: BCR), IgD, CD1c, CD35 (complement receptor 1 (CR1)), CD21 (complement receptor 2 (CR2)), CD27, high levels of Toll-like receptors (TLR), MHC class II, and TACI (an Ig-inducing receptor) [13,80]. Through the dual binding of antigens to the BCR and TLR, MZ B cells are promptly activated, undergoing Ig class switching and somatic hyper-mutation in a T cell-independent manner. In mice it has been shown that under certain stimuli, and using CR1, CR2 and the chemotactic receptors S1P1 and CXCR5, MZ B cells migrate, shuttling antigens to the $B$ cell follicles [81], returning afterwards back to the MZ. When only the BCR is stimulated, MZ B cells migrate to the $\mathrm{T}$ cell zone to develop a $\mathrm{T}$ cell-dependent antibody response. Through TACI receptors, MZ B cells receive assistance by the $\mathrm{N}_{\mathrm{BH}}$ to produce IgM and for class switching from IgM to IgG or IgA in a T cell-independent manner [16]. Other important populations in the $M Z$ are the already mentioned macrophages as well as DCs, ILC3 and switched memory B cells [9]. NKT cells have been found in human spleen tissue [82]; however, its localization within the spleen is not clear. In mice on the other hand, NKT cells have been found in the MZ and $\mathrm{RP}$ initiating protective immune responses against bloodborne antigens [14].

Depletion of cells in the MZ during acute malaria infection was reported in the Plasmodium chabaudi AS infection mouse model [83]. Later on, Urban and collaborators found a marked dissolution of $\mathrm{MZ}$ with loss of $B$ cells in human spleens of adult patients dying from $P$. falciparum malaria although not significant [84]. Recently, it was shown that acute P. chabaudi AS infection in mice causes apoptosis of transitional T2 and $\mathrm{MZ} \mathrm{B}$ cells during and subsequent to the control of the first wave of parasitaemia [85]. These findings have been corroborated by several reports of apoptosis of different immune cells in the spleen in malaria animal models [86-89]. A proposed underlying mechanism of reduced $B$ cells in the spleen is the impaired generation of bone marrow MZ B cell precursors. Regarding the malaria-driven apoptosis mechanism, it has been proposed to be mediated by pro-inflammatory cytokines such as TNF [13], functional exhaustion of the MZ due to abnormally high influx of parasitic antigens [12,13], and the synergy between the accumulation of free haem in plasma during Plasmodium infection and TNF production, that mediates programmed cell death in immune cells [90].

As explained, the development of peripheral B cells takes place during infancy. However, in malaria-endemic settings some alterations in B cell subsets independent of age have been reported [91]. For instance, a study performed in western Kenya found suppression of circulating $\mathrm{IgD}^{+} \mathrm{CD} 27^{+} \operatorname{IgM}^{+} \mathrm{B}$ cells (the peripheral equivalent of $\mathrm{MZ}$ $B$ cells) in infants aged one to 24 months living in a malaria-endemic region when compared with a similar infant population from an unstable malaria transmission region [91]. Supporting these findings, it has been reported that four- to five-year old children in Uganda with the highest incidence of malaria in the prior year of the study ( $>=$ seven episodes/year, $n=20$ ) exhibited a transient drop in frequencies of $\operatorname{IgD}^{+} \mathrm{CD} 27^{+} \operatorname{IgM}^{+} \mathrm{B}$ cells at the time of acute malaria, not seen in subjects with a lower incidence [92]. A recent study performed at the Barcelona Centre for International Health Research (CRESIB) also shows a decrease of MZ-like peripheral B cells in pregnant women from Papua New Guinea with life-long exposure to Plasmodium infections (Requena et al., in press $J$ Immunol). Here, it is hypothesized that the drop of the MZ B cells in peripheral circulation of patients with malaria is a result of the disruption in spleen architecture observed in the referred histology studies. Furthermore, the MZ B cell deficiency along with some other possible defective immune spleen functions appears to be responsible for a transient hyposplenism in children with malaria, increasing their risk to IBI. Importantly, children with malaria have been reported to show a lower antibody response against group $\mathrm{C}$ meningococcal polysaccharide vaccines when compared to children from the same setting but without parasitaemia, supporting this hypothesis [27]. In line with this finding, 
immunological memory against previous vaccinations, including diphtheria toxoids, is lost in animal models after malaria episodes by deletion of memory B cells and longlived plasma cells in spleen and bone marrow [93].

Taking into account that the spleen MZ has not yet reached maturity in young children, it can be speculated that the threshold of MZ dysfunction (due to falciparum malaria or other pathologies) that is needed to develop immune hyposplenism is lower in children when compared to the adult population, probably explaining children's increased susceptibility to bacteraemia in the context of malaria infection when compared to the immune-competent adult population.

It is important to clarify that the peripheral equivalent of the MZ B cells have different nomenclatures in the research literature: MZ-like B cells, IgM memory B cells [94], splenic MZ B cells (S-MZ B cells) [7], IgD + IgM + CD27+ B cells, IgD + CD27+ B cells [91] and CD27 + IgM + B cells.

\section{Observation 3. Antibody and complement are necessary to control NTS invasive infection}

NTS bacteraemia most commonly occurs in African children below two years of age. A relative sparing of infants younger than four months old has been found coincidently within the period during which maternal antibodies are still present [95]. Sera from healthy children less than 16 months old were shown to lack NTS-specific antibodies, and sera lacking antibodies did not kill NTS despite normal complement function [96]. Additionally, Salmonella-specific antibodies facilitate specific $\mathrm{T}$ cell responses via augmentation of bacterial uptake and induction of apoptosis in macrophages [97]. Moreover, transferred low- and high-affinity IgG2c, and with less efficiency IgM, were shown to impede Salmonella colonization of splenic macrophages, markedly reducing bacteraemia by antibodies induced during the infection in mice [98]. Therefore, as the fast antibody response against encapsulated bacteria is developed in the spleen, here it is postulated that malaria-induced hyposplenism could be responsible for a defective immune response against NTS and other encapsulated bacteria in children with malaria, substantially increasing their risk to develop IBI.

\section{Observation 4. Children with SMA have a higher prevalence} of IBI co-infections than children with cerebral malaria

A study in Sudanese children reported that SMA was associated with a larger spleen, longer fever duration and lower parasitaemia than cerebral malaria (CM) [99]. In these children, SMA and CM clinical presentation differed significantly in several aspects, including median age (three versus six years), prevalence of splenomegaly (57 versus 11\%), and spleen size (Hackett grade 3.5 versus 0 ). Recently, a study reported that spleen volume measured by ultrasonography was lower in children with CM compared with children with SMA [100]. Interestingly, similar results were found some decades ago in an animal model of malaria infection in which resistant mouse strains developed marked splenomegaly and survived the infection, whilst susceptible mice succumbing to the infection developed only minimal splenomegaly [83]. In humans, SMA is more prevalent in children younger than two years old in holo-endemic areas $[18,99,101]$. Therefore, there is an age-dependent variation of iRBC clearance, with older patients having less efficient parasite clearance than young children, suggesting an innate retention process [99]. Previous findings reported that patients with malaria and splenomegaly markedly accelerated clearance of ${ }^{51} \mathrm{Cr}$-labelled RBC and presented with a lower mean haematocrit than patients without splenomegaly [102]. Filtration-based parasite clearance is likely the key to spleen-dependent innate protection [99]. However, how this innate function of the spleen protects against malaria parasites and how the retention of $i R B C$ and uninfected $R B C$ (uRBC) in this organ influences immunologic response in the young host has not yet been studied.

Of note, several studies have shown that children with SMA have a higher prevalence of IBI co-infections (largely NTS bacteraemia) compared with children with $\mathrm{CM}$ who infrequently have bacterial co-infections [32,33,103]. The increased malaria parasite clearance in SMA would explain the reported tendency of children with malaria and IBI co-infection to have lower parasite densities $[31,33,103]$, as well as the low frequency of NTS infection in children with high malaria parasite counts [43,104]. Therefore, the 'SMA-IBI-young age' association needs to be elucidated. A possible innate mechanism that could explain the prevalence of SMA in young children is the age-related change in $\mathrm{RBC}$ complement regulatory proteins (CRP) $[101,105,106]$. The detailed discussion of this possible mechanism is beyond the scope of this manuscript. Briefly, CRPs are in low concentration on the surface of $R B C$ in young children, increasing the splenic erythrophagocytosis of $i R B C$ and $u R B C$ during malaria infection, as compared to the adult population $[107,108]$, with the consequent development of splenomegaly. It has been found that splenomegaly in malaria patients is the result of splenic accumulation of iRBCs, uRBCs, macrophages, and reticular cells [99], among other cells. It was mentioned earlier that under normal conditions the splenic RP reaches a haematocrit of $80 \%$. Therefore, during malaria infection, the increased amount of entrapped RBCs in the RP requires some tissue rearrangements. Two animal models illustrate two different possible situations in the presence of Salmonella typhimurium or S. pneumoniae bacteria with parasitic co-infection of the spleen. Apparently, co-infection by a non-lethal Plasmodium strain and S. typhimurium in mice does not alter 
the compartmental distribution of malaria $\mathrm{ARBC}$ and bacteria in the spleen [109]. Malaria iRBC in these experiments were located in the RP, and bacteria were located in the MZ (Figure 2A). Taking all limitations of the mouse model into account, both micro-organisms were successfully cleared, demonstrating conserved haematological and immunological spleen functions despite the concomitant infections. Another research group decided to test the bactericidal function of the spleen in the absence of MZ. Mice with chronic Leishmania donovani infection (which presents with progressive loss of macrophages in the MZ in direct relation to splenomegaly) were coinfected with S. pneumoniae. In this case, in the absence of MZ macrophages, bacteria were located in the RP instead of the MZ, and phagocytosed by RP macrophages, showing a relocalization of the bactericidal functions in the spleen [110] (Figure 2B). However, here it is postulated that in the case of invasive bacterial co-infection with a lethal malaria parasite strain, such as $P$. falciparum, this relocalization will not occur due to overload of RBC in the $\mathrm{RP}$, among other factors. In human P. falciparum malaria, similarly to the L. donovani-S. pneumoniae co-infection, the MZ would be significantly reduced. Nevertheless, some important differences with this animal model would be: 1$)$ the chronicity of infection in this $L$. donovani animal model, in contrast with acute $P$. falciparum malaria in humans, perhaps implying that the total phagocytic capacity of the spleen RP is not necessarily overwhelmed in chronic Leishmania infections - even though in massive splenomegaly cases of $L$. donovani in humans, the important structural changes in the spleen might impact its immunological function; 2) the high parasitaemia and splenic overload with $\mathrm{iRBC}$ and $\mathrm{uRBC}$ in the case of
P. falciparum malaria, added to the increased erythrophagocytic capacity in young children, that will demand maximum phagocytic capacity from the macrophages in the RP and the MZ [111] (Figure 3). Importantly, in the case of falciparum malaria, even if bacteria reach the RP, the chances to be phagocytosed there will be low. The reason is the evidence arising from experiments performed in in vivo animal models and in vitro [78]. These studies show that macrophages simultaneously exposed to damaged RBC and S. typhimurium organisms preferentially phagocytose damaged $\mathrm{RBC}$, presenting a defective bactericidal capacity. The reasons are not clear. It is postulated that inhibition of bacterial phagocytosis may be mediated by competition mechanisms between damaged RBC and bacteria for phagocytic sites on macrophages, or that macrophages are just overloaded temporarily [111].

\section{Putting two and two together}

Synthesizing the above information, it is evident that due to innate mechanisms, African children younger than three years old develop SMA with accompanied splenomegaly more frequently than older children and adults. The changes in the immune cell architecture of the spleen under these circumstances might affect the immunological function of this organ against encapsulated bacteria. Initially by disruption and almost disappearance of the MZ and its important fast bactericidal function, but also by impairing other spleen functions like the production of tuftsin, presenting opsonization failure and defective function of the alternative complement pathway. In $P$. falciparum infections, the phagocytic capacity of the spleen in young children might be saturated, with RP macrophages preferentially phagocytosing

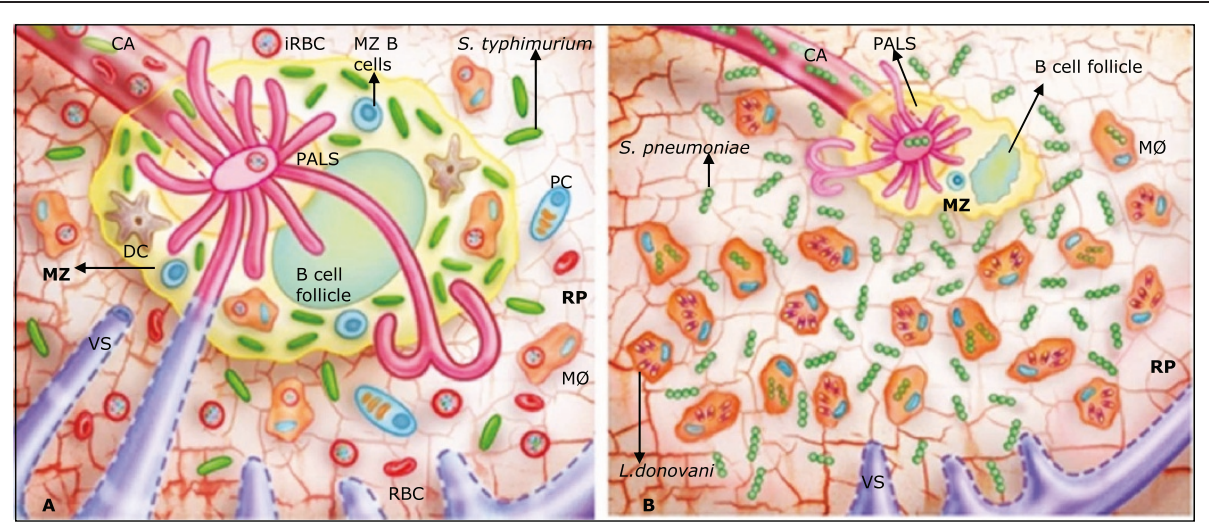

Figure 2 Parasite and bacteria co-infection in the rodent spleen. A. Plasmodium chabaudi - Salmonella typhimurium co-infection in the rodent spleen. Adapted from Yavada et al. [109]. The white pulp (periarteriolar lymphoid sheaths (PALS) and B cell follicle) and the marginal zone (MZ) do not show atrophy and preserve their function. B. Leishmania donovani - Streptococcus pneumoniae co-infection in the rodent spleen. Adapted from Kirby et al. [110]. The white pulp and the MZ are notoriously atrophic, showing great amounts of macrophages with phagocytosed amastigotes of L. donovani. In the absence of MZ, S. pneumoniae localized in the red pulp (RP) where RP macrophages compensate the MZ dysfunction. CA: central arteriole; VS: venous sinuses; RBC: red blood cell; iRBC: infected RBC; MØ: macrophages; PC: plasma cells; DC: dendritic cells; MZ B cells: marginal zone B cells. The perifollicular zone (PFz) was not drawn in these Figures. 


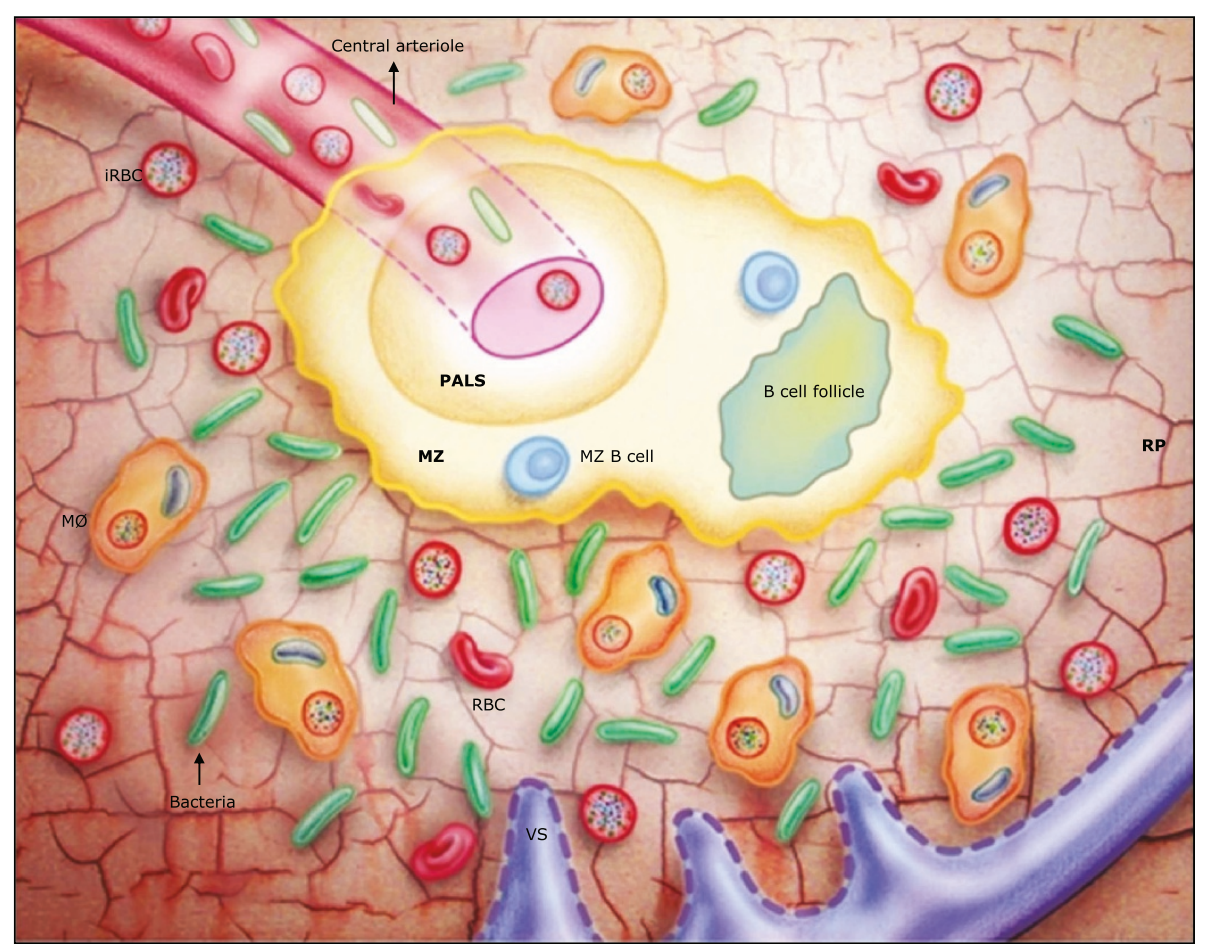

Figure 3 Plasmodium falciparum and invasive bacterial co-infection in the human spleen. The marginal zone (MZ) during P. falciparum malaria is dissolved, therefore lacking its most important armamentarium against encapsulated bacteria. The red pulp (RP) macrophages phagocytic capacity is overload by erythrophagocytosis, and in the presence of infected erythrocytes, macrophages will deficiently phagocytose bacteria. Bacteria replicate rapidly causing bacteraemia. (MØ) macrophages; (VS) venous sinuses. Penicilli and perifollicular zone (PFz) were not incorporated into this Figure.

iRBC over bacteria [78,111]. As a consequence, in the case of a bloodstream invasion of bacteria at the same time as $P$. falciparum infection, bacteria will find the MZ almost inhabited and the RP macrophages busy and skewed to $\mathrm{iRBC}$ and $\mathrm{uRBC}$ phagocytosis. Subsequently, bacteraemia takes place (Figure 3 and 4).

\section{Additional mechanisms Bacterial carriage status}

It is highly likely that children who develop malaria-IBI co-infection are carriers of the causative bacteria when they develop malaria infection. There is evidence that $6.9 \%$ of household contacts of children with IBI by NTS are asymptomatic carriers of NTS in the stools, including healthy children [112]. Additionally, NTS seems to behave like an opportunistic infection $[29,113,114]$, being highly prevalent among adult HIV patients, with a $23 \%$ prevalence of NTS found in spleen tissue from adult HIV individuals dying from a different cause [44]. This carriage state postulate is underpinned by the clinical case of a 14 month old child that presented with an invasive infection by $S$. typhimurium after splenectomy due to acute spleen torsion [115]. This is a very close analogy to cases of young children with malaria - an otherwise healthy child, possibly carrier of NTS in the intestine, who suddenly suffers from a hyposplenic state due to a surgical resection of the spleen, which in the case of young African children would be represented by hyposplenism caused by $P$. falciparum malaria infection.

Malaria infection impairs mucosal inflammatory response As mentioned, NTS cause high rates of life-threatening bacteraemia in the immune-compromised host and in infants in sub-Saharan Africa, resulting in mortality rates surpassing 20\% despite antibiotic treatment [29,113]. Mucosal barriers represent the first line of defence against bacteria, where lymphoid tissues located between the host and the environment endow with immune cells capable to mount innate and adaptive immune responses against these pathogens [9]. Once bacteria have penetrated the mucosal barrier, the invading micro-organism translocates to the intestinal lymph follicles and the draining mesenteric lymph nodes (MLNs), and some pass on to the reticulo-endothelial cells of the liver and spleen [113]. It has been postulated that malaria infection favours bacteria translocation from the intestinal lumen to the blood, with animal models clearly proving this hypothesis by isolating S. typhimurium from liver and spleen by approximately 1,000-fold in animals co-infected with malaria when compared with control animals [114]. These results have been 


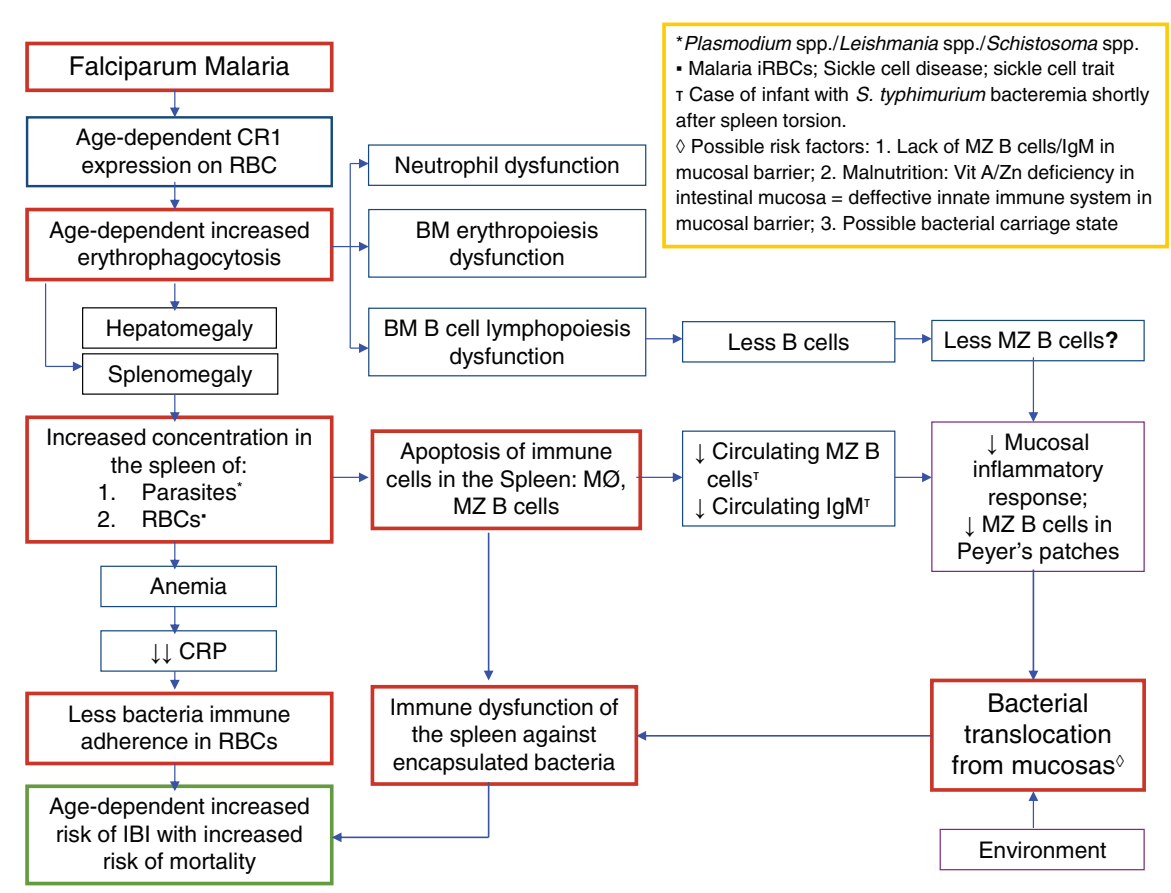

Figure 4 Summary of possible key events leading to bacterial co-infection in young children with Plasmodium falciparum malaria. RBC: red blood cell; BM: bone marrow; MZ B cells: marginal zone B cells; MØ: macrophages; IBI: invasive bacterial infection; CRP: complement regulatory proteins.

corroborated by the same research group [29] in elegant studies in non-human primate and murine animal models. In these experiments, malaria infection led to increased recovery of S. typhimurium from the draining MLNs in mice. Furthermore, malaria infection caused a global suppression of gut inflammatory response and reduced significantly the neutrophil influx to intestinal mucosa, characteristic of NTS infection. IL-10 produced during malaria infection, an anti-inflammatory cytokine whose function is to control the pathogenic inflammatory response against malaria parasites [28], was found to contribute to the suppression of mucosal inflammatory response to invasive NTS in these animal models. However, further mechanisms for bacterial translocation from mucosal surfaces in malaria patients need to be explored; for instance, to study the impact of a reduced amount of circulating MZ B cells in children with malaria in mucosa immune response, since in humans MZ B cells are also located in the subepithelial area of mucosa-associated lymphoid tissues (MALT), including Peyer's patches and the epithelium of tonsilar crypts [13].

\section{Vitamin A deficiency}

Immune cells have homing molecules resembling immune post-codes' allowing them to be recruited to specific organs, such as the intestine or skin [116]. Hence, vitamin A plays an important role in the intestinal immune system as a source of retinoic acid (RA), a gut-homing factor for IgA secreting cells in intestinal mucosa $[117,118]$. Furthermore, intestinal epithelial cells send signals through RA to DCs in the gut lamina propria promoting IgA class switching in local B cells [118]. It has been shown some decades ago that malnourished vitamin A-deficient rats exhibit impaired migration of recently activated mesenteric lymphocytes, in addition to a marked decrease in the number of IgA-antibody secreting cells and $\mathrm{CD} 4^{+} \mathrm{T}$ cells in the ileum [117]. Moreover, gestational vitamin A deficiency in animal models has been shown to reduce the intestinal immune response by decreasing the number of immune cells in rat offspring [119] and controlling the size of secondary lymph organ and the efficiency of immune responses in the adult mouse offspring [120]. As severe malnutrition is one of the risk factors to develop malaria-IBI co-infection, it is important to evaluate the impact of vitamin A administration in the clinical management of children with malaria and IBI-co-infection in Africa, either as a therapeutic and/or prophylactic measure, especially due to recent evidence of the positive impact of vitamin A and zinc supplementation on malaria morbidity in a study conducted in Ghana [121,122]. However, in man, the role of vitamin A in malaria pathogenesis is multifaceted, and $P$. falciparum clearly benefits from normal to high vitamin A hepatic stores, possibly depending on scavenged vitamin A metabolites to destabilize host RBC membranes facilitating invasion [123]. 


\section{Some loose ends}

If splenomegaly and the excessive B cell stimulation in the spleen are the cause of immunological hyposplenism in young children with malaria, it should be expected that patients with other parasitic diseases that cause splenomegaly also develop an increased susceptibility to IBI. There are few reported cases in the literature of increase susceptibility to IBI by NTS in cases of leishmaniasis [124,125] and schistosomiasis [126,127]. Although, in the latter co-infection, some more complex mechanisms related to adhesion of bacteria to the Schistosoma parasites might be related to recurrent NTS infection. It is interesting that in the case of schistosomiasis, the increased risk to IBI by NTS is also apparently restricted to young children [128]. However, the case of Plasmodium vivax malaria and the weak correlation of this infection with IBI is a matter of reflection, especially taking into account that $P$. vivax malaria presents more frequently with massive splenomegaly than $P$. falciparum malaria. That notwithstanding, the concomitant infection of Salmonella typhi and P. vivax is well established [129-134]. However, the postulated mechanism of this association is the activation of vivax malaria hypnozoites by systemic parasitic and bacterial infections, with little current evidence of $P$. vivax malaria association with other bacterial infections [135]. What could be the explanation for such a prominent splenomegaly without evident immune hyposplenism? A possible mechanism is that in the case of $P$. vivax malaria, the inflammatory response of the $B$ cell subset in the spleen is different, meaning that despite the important capture of infected reticulocytes in the spleen of $P$. vivax malaria patients, the immune reaction is somehow not as strong as in the case of $P$. falciparum malaria (that infects both reticulocytes and mature RBC), therefore not causing a major impact on MZ function. A possible hypothesis to explain this phenomenon could be that $P$. vivax malaria, by infecting reticulocytes, is protected by their CD47 membrane protein, a potent "do not eat me" signal to macrophages in the spleen [136]. Interestingly, CD47 is expressed to a higher level in reticulocytes than in mature RBC $[137,138]$. The "do not eat me" signal provided by $\mathrm{CD} 47$ has been proven to be strong enough to prevent phagocytosis of antibody opsonized tumour cells when these cells express high quantities of CD47 [139]. Therefore, the expression of CD47 may just be high enough to prevent phagocytosis after $P$. vivax infection. In addition, CD47 has been shown to undergo a conformational change after oxidation, a state that will lead to an "eat me" configuration, which will result in phagocytosis by RP macrophages [136]. It is well known that Plasmodium infection leads to reactive oxygen species (ROS) formation, which may lead to oxidation of CD47 and thus the "eat me" configuration of this protein. Reticulocytes, however, have a far better capacity to handle oxidative damage than mature RBC. Thus, infection of reticulocytes by $P$. vivax may not lead to CD47 oxidation and the switch from "do not eat me" to "eat me" signal would not take place, whereas during infection of mature RBC CD47 may be well oxidized. Together, the higher expression of CD47 and the better protection of reticulocytes against ROS generation might explain the accumulation of a big amount of infected reticulocytes in the spleen and the consequent splenomegaly in $P$. vivax malaria, due to the inability of RP macrophages to phagocytose them. In the case of this hypothetical incapacity of the RP to phagocytose $P$. vivax-infected reticulocytes, it is possible that different immunological pathways are triggered when compared to P. falciparum malaria, perhaps affecting in a different way or to a lesser extent the MZ immune cell compartment of the spleen.

Additionally, it is important to clarify that the human spleen has remarkable differences compared to the murine spleen, for instance regarding its microcirculation (open in mice, closed and open in humans) and anatomic characteristics (absence of perifollicular zone in mice; absence of marginal sinus in humans) $[10,13,94]$. Also, MZ B cells do not circulate in mice, while they do in humans. Therefore, animal models were included here as a source of valuable information about the dynamic changes of immune cells in this organ in the context of bacterial and parasitic infections, because such studies are not possible to perform in humans. However, this information should be carefully examined and not directly translated to the human case.

\section{Concluding remarks}

There is ample evidence in the scientific literature to support the hypothesis postulated here that African children younger than three years of age might present with immunological spleen dysfunction triggered by $P$. falciparum malaria infection. However, malaria-dependent hyposplenism could possibly affect older children in subSaharan Africa as well. This hypothesis is based upon several observations in human spleen histology studies and immune cells in peripheral blood, indicating alterations in the structure and function of the spleen, particularly of the MZ. Animal models, with their acknowledged limitations, were analysed as well in detail and corroborated these findings, opening new questions that need to be urgently addressed in the human host. Testing the dysfunctional spleen hypothesis postulated here would have important implications for bedside care of African children with malaria.

For instance, the development of simple and affordable methods to assess the immune spleen function in children with malaria and other parasitic diseases that colonize the spleen should be a priority because current tools are largely oriented to evaluate the haematological but not the 
immunological function of this organ. Importantly, as young children lack protective antibodies against several encapsulated bacteria when they face a $P$. falciparum infection, it is necessary to evaluate the role that adjuvant intravenous g-globulin and/or tuftsin treatment could play in helping them overcome their splenic opsonization failure when encountering malaria-IBI co-infections. In this regard, it should be a main concern to accelerate the introduction of several vaccines missing in the expanded programme on immunization in most African countries. In addition, the risk of malaria-IBI co-infection in children from these countries should be taken into account by international organizations and funding sources supporting vaccine introduction in poor countries to orientate their immunization strategies, as well as to increase their investment in research and development of vaccines against NTS.

Assuming that bacteria colonize mucosal surfaces in children and, in the presence of malaria infection, translocate to the bloodstream, it would be important to evaluate the role of probiotics in improving the immune response to IBI in very young children at the first line of defence against these pathogens: the mucosal barrier. Some studies have shown that oral probiotic treatment importantly reduced late onset sepsis in newborns [113], remarkably even against S. pneumoniae infection [140]. Of note, the microbiota plays a key role in regulating the host immune system [113,141], and in the specific case of the genus Salmonella, optimizes its response against this micro-organism and mediates pathogen clearance [113]. On the other hand, in some cases prophylactic antibiotic therapy is indicated in children in resourcelimited African countries to prevent bacterial infections due to the limited access to health facilities and the difficult medical follow-up. However, as antibiotic treatment, reduces the gut microbiota, it is important to be cautious when given this prophylaxis in children with severe malaria, since the impact on the immune system of the gut could be deleterious, besides the risk of developing antibiotic resistance. Therefore, it is necessary to evaluate the role of probiotics as prophylactics against IBI, as well as adjuvant therapy during and after treatment of bacterial infections, to help the maturity of the immune system and to overcome the effect of antimicrobials in the gut microbiota, respectively, to reduce the morbidity and mortality of bacterial infections in young children.

The time gap between generation of knowledge and its application where is greatly needed is unfortunately long. The aim of this review is to reduce this time gap as much as possible by sharing information considered of value for the malaria research community. The proposed dysfunctional spleen hypothesis needs to be confirmed or rejected by studies in human subjects directly addressing the immune spleen function, since no studies of this kind have ever been performed in African children with malaria. Meanwhile, a general awareness to the health care providers that young children with $P$. falciparum malaria should be treated as hyposplenic patients is advised.

\begin{abstract}
Abbreviations
${ }^{51}$ Cr: Chromium-51; ${ }^{99 m} \mathrm{TC}$ : Tecnecio-99 m; BCR: B cell receptor; BM: Bone marrow; CM: Cerebral malaria; CR1: Complement receptor 1; CR2: Complement receptor 2; CRP: Complement regulatory proteins; CXCR5: Chemokine receptor 5; DCs: Dendritic cells; FSV: Functional splenic volume; HIV: Human immunodeficiency virus; HJB: Howell Jolly bodies; IBI: Invasive bacterial infections; IES: Interendothelial slits; Ig: Immunoglobulin; IgA: Immunoglobulin A; IgD: Immunoglobulin D; IgG2C: Immunoglobulin G2C; IgM: Immunoglobulin M; IL-10: Interleukin 10; ILC3: Innate lymphoid cells type 3; MALT: Mucosal associated; MHC: Major histocompatibility complex molecule; MLNs: Mesenteric lymph nodes; MØ: Macroghages; MZ: Marginal zone; MZ B cells: Marginal zone B cells; $N_{B H}$ : B cell-helper neutrophils; NK cells: Natural killer cells; NKT: Natural killer T cells; NTS: Non-typhi salmonella; OPSI: Overwhelming post-splenectomy infection syndrome; PALS: Periarteriolar lymphoid sheath; PC: Plasma cells; PMN: Polymorphonuclear neutrophils; PV: Portal vein; PFz: Perifollicular zone; RA: Retinoic acid; RBC: Red blood cell; iRBC: Infected red blood cells; URBC: Uninfected red blood cells; ROS: Reactive oxygen species; RP: Red pulp; S1P1: Sphingosine 1-phosphate receptor; SCD: Sickle cell disease; SC: SCD heterozygous phenotype; SS: SCD homozygous genotype; SMA: Severe malarial anaemia; SMV: Superior mesenteric vein; SV: Splenic vein; TACl: Transmembrane activator and CALM interactor; TI: T cell independent; TI-1: TI response against polysaccharide microorganism antigens; TI-2: TI response against lipopolysaccharide microorganism antigens; TLR: Toll-like receptors; TNF: Tumour necrosis factor alfa; Transitional T2 B cells: Transitional B cells
\end{abstract} type 2; VS: Venous sinuses; WP: White pulp.

\section{Competing interests}

The authors declare that they have no competing interests.

\section{Authors' contributions}

GPGP performed the literature review, formulated the core hypothesis, designed the figures and wrote the first manuscript draft. CD, MPG and RvB discussed the hypothesis and contributed to its refinement and participated in the writing. All authors read and approved the final manuscript.

\section{Acknowledgements}

We thank all the scientists from different disciplines dedicated to the study of this mysterious and fascinating organ: the spleen. We are grateful to all researchers dedicated to the study of malaria, especially of the burden of this disease in children. We would like to thank Hernando del Portillo for sharing useful information about the spleen function and anatomy; to Eleanor Riley, Pilar Requena, Quique Bassat, Thomas Williams, Pedro Alonso, Ineke ten Berge, Martijn Nolte, Giuliana Magri, and Andrea Cerutti for thoughtful discussions on the hypothesis. We are grateful to Giselle Vitali for drawing the figures. GPGP holds a European Commission - Erasmus Mundus Joint Doctorate Programme scholarship.

\section{Author details}

${ }^{1}$ Barcelona Centre for International Health Research (CRESIB, Hospital Clínic-Universitat de Barcelona), Barcelona 08036, Spain. ${ }^{2}$ Centre of Tropical Medicine and Travel Medicine, Department of Infectious Diseases, Academic Medical Centre, University of Amsterdam, Meibergdreef 9, PO Box 22660, 1100 DD Amsterdam, The Netherlands. ${ }^{3}$ Department of Blood Cell Research, Sanquin Research and Landsteiner Laboratory, Academic Medical Center, University of Amsterdam, Plesmanlaan 125, 1066CX Amsterdam, The Netherlands.

Received: 2 June 2014 Accepted: 21 August 2014 Published: 26 August 2014

\section{References}

1. Ogilvie C, Evans C: Splenomegaly. In Chamberlaine's Symptoms and Signs in Clinical Medicine. 11th edition. Edited by Ogilvie C, Evans C. Brucks, Butterworth: EBLS; 1987. 
2. Doolan DL: Malaria Methods and Protocols. Totowa, New Yersey: Humana Press Inc; 2002.

3. Weill JC, Weller S, Reynaud CA: Human marginal zone B cells. Annu Rev Immunol 2009, 27:267-285.

4. Weller S, Mamani-Matsuda M, Picard C, Cordier C, Lecoeuche D, Gauthier F, Weill JC, Reynaud CA: Somatic diversification in the absence of antigen-driven responses is the hallmark of the $\lg M+\lg D+C D 27+B$ cell repertoire in infants. J Exp Med 2008, 205:1331-1342.

5. Timens W, Boes A, Rozeboom-Uiterwijk T, Poppema S: Immaturity of the human splenic marginal zone in infancy. Possible contribution to the deficient infant immune response. J Immunol 1989, 143:3200-3206.

6. Bowdler A: The Complete Spleen: Structure, Function and Clinical Disorders. 2nd edition. New Yersey: Humana Press; 2002.

7. Zandvoort A, Timens W: The dual function of the splenic marginal zone: essential for initiation of anti-Tl-2 responses but also vital in the general first-line defense against blood-borne antigens. Clin Exp Immunol 2002, 130:4-11.

8. Martin F, Oliver AM, Kearney JF: Marginal zone and B1 B cells unite in the early response against T-independent blood-borne particulate antigens. Immunity 2001, 14:617-629.

9. Magri G, Miyajima M, Bascones S, Mortha A, Puga I, Cassis L, Barra CM, Comerma L, Chudnovskiy A, Gentile M, Llige D, Cols M, Serrano S, Arostegui I, Juan M, Yague J, Merad M, Fagarasan S, Cerutti A: Innate lymphoid cells integrate stromal and immunological signals to enhance antibody production by splenic marginal zone B cells. Nat Immunol 2014, 15:354-364.

10. Mebius RE, Kraal G: Structure and function of the spleen. Nat Rev Immunol 2005, 5:606-616.

11. Lammers AJ, de Porto AP, Bennink RJ, van Leeuwen EM, Biemond BJ, Goslings JC, van Marle J, ten Berge IJ, Speelman P, Hoekstra JB: Hyposplenism: comparison of different methods for determining splenic function. Am J Hematol 2012, 87:484-489.

12. Krucken J, Mehnert LI, Dkhil MA, El-Khadragy M, Benten WP, Mossmann H, Wunderlich F: Massive destruction of malaria-parasitized red blood cells despite spleen closure. Infect Immun 2005, 73:6390-6398.

13. Cerutti A, Cols M, Puga I: Marginal zone B cells: virtues of innate-like antibody-producing lymphocytes. Nat Rev Immunol 2013, 13:118-132.

14. Barral P, Sanchez-Nino MD, van Rooijen N, Cerundolo V, Batista FD: The location of splenic NKT cells favours their rapid activation by blood-borne antigen. EMBO J 2012, 31:2378-2390.

15. Steiniger $B$, Barth $P$, Hellinger $A$ : The perifollicular and marginal zones of the human splenic white pulp : do fibroblasts guide lymphocyte immigration? Am J Pathol 2001, 159:501-512.

16. Puga I, Cols M, Barra CM, He B, Cassis L, Gentile M, Comerma L, Chorny A, Shan M, Xu W, Magri G, Knowles DM, Tam W, Chiu A, Bussel JB, Serrano S, Lorente JA, Bellosillo B, Lloreta J, Juanpere N, Alameda F, Baro T, de Heredia CD, Toran N, Catala A, Torrebadell M, Fortuny C, Cusi V, Carreras C, Diaz GA: $B$ cell-helper neutrophils stimulate the diversification and production of immunoglobulin in the marginal zone of the spleen. Nat Immunol 2012, 13:170-180

17. Henry K, Symmers WSC: Thymus, Lymph Nodes, Spleen and Lymphatics. In Sytemic Pathology. 3rd edition. New York: Churchill Livingstone; 1992.

18. Buffet PA, Safeukui I, Deplaine G, Brousse V, Prendki V, Thellier M, Turner GD, Mercereau-Puijalon O: The pathogenesis of Plasmodium falciparum malaria in humans: insights from splenic physiology. Blood 2011, 117:381-392.

19. Kraal G, Mebius R: New insights into the cell biology of the marginal zone of the spleen. Int Rev Cytol 2006, 250:175-215.

20. Weiss L: The spleen in malaria: the role of barrier cells. Immunol Lett 1990, 25:165-172.

21. Schwarzer E, Turrini F, Ulliers D, Giribaldi G, Ginsburg H, Arese P: Impairment of macrophage functions after ingestion of Plasmodium falciparum-infected erythrocytes or isolated malarial pigment. J Exp Med 1992, 176:1033-1041.

22. Cunnington AJ, de Souza JB, Walther M, Riley EM: Malaria impairs resistance to Salmonella through heme- and heme oxygenase-dependent dysfunctional granulocyte mobilization. Nat Med 2012, 18:120-127.

23. Urban BC, Roberts DJ: Malaria, monocytes, macrophages and myeloid dendritic cells: sticking of infected erythrocytes switches off host cells. Curr Opin Immunol 2002, 14:458-465.

24. Weiss GE, Crompton PD, Li S, Walsh LA, Moir S, Traore B, Kayentao K, Ongoiba A, Doumbo OK, Pierce SK: Atypical memory B cells are greatly expanded in individuals living in a malaria-endemic area. $J$ Immunol 2009, 183:2176-2182.

25. Weiss GE, Clark EH, Li S, Traore B, Kayentao K, Ongoiba A, Hernandez JN Doumbo OK, Pierce SK, Branch OH, Crompton PD: A positive correlation between atypical memory $B$ cells and Plasmodium falciparum transmission intensity in cross-sectional studies in Peru and Mali. PLoS One 2011, 6:e15983

26. Illingworth J, Butler NS, Roetynck S, Mwacharo J, Pierce SK, Bejon P, Crompton PD, Marsh K, Ndungu FM: Chronic exposure to Plasmodium falciparum is associated with phenotypic evidence of $B$ and $T$ cell exhaustion. J Immunol 2013, 190:1038-1047.

27. Greenwood BM, Bradley AK, Blakebrough IS, Whittle HC, Marshall TF, Gilles HM: The immune response to a meningococcal polysaccharide vaccine in an African village. Trans $R$ Soc Trop Med Hyg 1980, 74:340-346.

28. Portugal S, Moebius J, Skinner J, Doumbo S, Doumtabe D, Kone Y, Dia S, Kanakabandi K, Sturdevant DE, Virtaneva K, Porcella SF, Li S, Doumbo OK Kayentao K, Ongoiba A, Traore B, Crompton PD: Exposure-dependent control of malaria-induced inflammation in children. PLOS Pathog 2014, 10:e1004079.

29. Mooney JP, Butler BP, Lokken KL, Xavier MN, Chau JY, Schaltenberg N, Dandekar S, George MD, Santos RL, Luckhart S, Tsolis RM: The mucosal inflammatory response to non-typhoidal Salmonella in the intestine is blunted by IL-10 during concurrent malaria parasite infection. Mucosal Immunol 2014. Advance online publication, 26 March 2014.

30. Scott JA, Berkley JA, Mwangi I, Ochola L, Uyoga S, Macharia A, Ndila C, Lowe BS, Mwarumba S, Bauni E, Marsh K, Williams TN: Relation between falciparum malaria and bacteraemia in Kenyan children: a populationbased, case-control study and a longitudinal study. Lancet 2011, 378:1316-1323.

31. Bassat Q, Guinovart C, Sigauque B, Mandomando I, Aide P, Sacarlal J, Nhampossa T, Bardaji A, Morais L, Machevo S, Letang E, Macete E, Aponte $\mathrm{JJ}$, Roca A, Menendez C, Alonso PL: Severe malaria and concomitant bacteraemia in children admitted to a rural Mozambican hospital. Trop Med Int Health 2009, 14:1011-1019.

32. Bronzan RN, Taylor TE, Mwenechanya J, Tembo M, Kayira K, Bwanaisa L, Njobvu A, Kondowe W, Chalira C, Walsh AL, Phiri A, Wilson LK, Molyneux ME, Graham SM: Bacteremia in Malawian children with severe malaria: prevalence, etiology, HIV coinfection, and outcome. J Infect Dis 2007, 195:895-904.

33. Church J, Maitland K: Invasive bacterial co-infection in African children with Plasmodium falciparum malaria: a systematic review. BMC Med 2014, 12:31.

34. Nadjm B, Mtove G, Amos B, Walker NF, Diefendal H, Reyburn H, Whitty CJ: Severe febrile illness in adult hospital admissions in Tanzania: a prospective study in an area of high malaria transmission. Trans $R$ Soc Trop Med Hyg 2012, 106:688-695.

35. Berkley JA, Lowe BS, Mwangi I, Williams T, Bauni E, Mwarumba S, Ngetsa C, Slack MP, Njenga S, Hart CA, Maitland K, English M, Marsh K, Scott JA: Bacteremia among children admitted to a rural hospital in Kenya. N Engl J Med 2005, 352:39-47.

36. Mtove G, Amos B, von Seidlein L, Hendriksen I, Mwambuli A, Kimera J, Mallahiyo R, Kim DR, Ochiai RL, Clemens JD, Reyburn H, Magesa S, Deen JL: Invasive salmonellosis among children admitted to a rural Tanzanian hospital and a comparison with previous studies. PLoS One 2010, 5:e9244.

37. Oundo JO, Muli F, Kariuki S, Waiyaki PG, lijima Y, Berkley J, Kokwaro GO, Ngetsa CJ, Mwarumba S, Torto R, Lowe B: Non-typhi salmonella in children with severe malaria. East Afr Med J 2002, 79:633-639.

38. Brent AJ, Oundo JO, Mwangi I, Ochola L, Lowe B, Berkley JA: Salmonella bacteremia in Kenyan children. Pediatr Infect Dis $J$ 2006, 25:230-236

39. Feasey NA, Dougan G, Kingsley RA, Heyderman RS, Gordon MA: Invasive non-typhoidal salmonella disease: an emerging and neglected tropical disease in Africa. Lancet 2012, 379:2489-2499.

40. Graham SM, Walsh AL, Molyneux EM, Phiri AJ, Molyneux ME: Clinical presentation of non-typhoidal Salmonella bacteraemia in Malawian children. Trans R Soc Trop Med Hyg 2000, 94:310-314.

41. Feasey NA, Archer BN, Heyderman RS, Sooka A, Dennis B, Gordon MA, Keddy $\mathrm{KH}$ : Typhoid fever and invasive nontyphoid salmonellosis, Malawi and South Africa. Emerg Infect Dis 2010, 16:1448-1451.

42. Mandomando I, Macete E, Sigauque B, Morais L, Quinto L, Sacarlal J, Espasa M, Valles X, Bassat Q, Aide P, Nhampossa T, Machevo S, Ruiz J, Nhacolo A, 
Menendez C, Kotloff KL, Roca A, Levine MM, Alonso PL: Invasive non-typhoidal Salmonella in Mozambican children. Trop Med Int Health 2009, 14:1467-1474.

43. Maclennan CA: Out of Africa: links between invasive nontyphoidal salmonella disease, typhoid Fever, and malaria. Clin Infect Dis 2014, 58:648-650.

44. Morpeth SC, Ramadhani HO, Crump JA: Invasive non-Typhi Salmonella disease in Africa. Clin Infect Dis 2009, 49:606-611.

45. Di Sabatino A, Carsetti R, Corazza GR: Post-splenectomy and hyposplenic states. Lancet 2011, 378:86-97.

46. Gordon MA: Salmonella infections in immunocompromised adults. $J$ Infect 2008, 56:413-422.

47. Noriega LM, Van der Auwera P, Daneau D, Meunier F, Aoun M: Salmonella infections in a cancer center. Support Care Cancer 1994, 2:116-122

48. Ram S, Lewis LA, Rice PA: Infections of people with complement deficiencies and patients who have undergone splenectomy. Clin Microbiol Rev 2010, 23:740-780.

49. Roberts AR, Hilburg LE: Sickle cell disease with Salmonella osteomyelitis. J Pediatr 1958, 52:170-175.

50. Zumla A, Lewis D, Brown J: Ciprofloxacin treatment of recurrent Salmonella typhimurium septicaemia in a splenectomized and immunosuppressed patient. J Antimicrob Chemother 1988, 21:809-810.

51. Angelski CL, McKay E, Blackie B: A case of functional asplenia and pneumococcal sepsis. Pediatr Emerg Care 2011, 27:639-641.

52. Foschi FG, Trevisani F, Loggi E, Parazza M, Melotti C, Bedeschi E, Mingazzin L, Cappa FM, Cescon M, Andreone P, Grazi G, Stefanini GF, Bernardi M: Effect of liver transplantation on tuftsin activity and phagocytic activity of neutrophil granulocytes in patients with liver cirrhosis. Int Arch Allergy Immunol 2005, 137:258-262.

53. Hsu RB, Chen RJ, Chu SH: Nontyphoid Salmonella bacteremia in patients with liver cirrhosis. Am J Med Sci 2005, 329:234-237.

54. Eraklis AJ, Filler RM: Splenectomy in childhood: a review of 1413 cases. J Pediatr Surg 1972, 7:382-388.

55. Lammers AJ: Living without a spleen. Ned Tijdschr Tandheelkd 2010, 117:611-614.

56. van Egmond $M$, van Garderen $E$, van Spriel $A B$, Damen $C A$, van Amersfoort ES, van Zandbergen G, van Hattum J, Kuiper J, van de Winkel JG: FcalphaRI-positive liver Kupffer cells: reappraisal of the function of immunoglobulin A in immunity. Nat Med 2000, 6:680-685.

57. Overturf G, Powars D: Infections in sickle cell anemia: pathogenesis and control. Tex Rep Biol Med 1980, 40:283-292.

58. Wong WY, Overturf GD, Powars DR: Infection caused by Streptococcus pneumoniae in children with sickle cell disease: epidemiology, immunologic mechanisms, prophylaxis, and vaccination. Clin Infect Dis 1992, 14:1124-1136.

59. Luzzatto L: Sickle cell anaemia and malaria. Mediterr J Hematol Infect Dis 2012, 4:e2012065.

60. Kruetzmann S, Rosado MM, Weber $\mathrm{H}$, Germing U, Tournilhac O, Peter $\mathrm{HH}$, Berner R, Peters A, Boehm T, Plebani A, Quinti I, Carsetti R: Human immunoglobulin M memory B cells controlling Streptococcus pneumoniae infections are generated in the spleen. J Exp Med 2003, 197:939-945.

61. Wong WY: Prevention and management of infection in children with sickle cell anaemia. Paediatr Drugs 2001, 3:793-801.

62. El-Hazmi MA: Infections in sickle cell disease. Ann Saudi Med 1986, 6:33-41.

63. Romero-Legro I, Kadaria D, Murillo LC, Freire AX: Intravenous gammaglobulin as rescue therapy in a patient with sickle cell and septic shock. Tenn Med 2013, 106:29-31.

64. Navolotskaya EV: The second life of antibodies. Biochemistry (Mosc) 2014, 79:1-7.

65. Spirer Z, Weisman Y, Zakuth V, Fridkin M, Bogair N: Decreased serum tuftsin concentrations in sickle cell disease. Arch Dis Child 1980, 55:566-567.

66. Humbert JR, Winsor EL, Githens JM, Schmitz JB: Neutrophil dysfunctions in sickle cell disease. Biomed Pharmacother 1990, 44:153-158.

67. Agrawal AK, Gupta CM: Tuftsin-bearing liposomes in treatment of macrophage-based infections. Adv Drug Deliv Rev 2000, 41:135-146.

68. Horvati K, Bacsa B, Szabo N, David S, Mezo G, Grolmusz V, Vertessy B, Hudecz F, Bosze S: Enhanced cellular uptake of a new, in silico identified antitubercular candidate by peptide conjugation. Bioconjug Chem 2012, 23:900-907.

69. Liu X, Guo J, Han S, Yao L, Chen A, Yang Q, Bo H, Xu P, Yin J, Zhang Z: Enhanced immune response induced by a potential influenza $A$ vaccine based on branched M2e polypeptides linked to tuftsin. Vaccine 2012, 30:6527-6533.

70. Kumar P, Biswas S, Rao DN: Potentiation of immune response against the RESA peptides of Plasmodium falciparum by incorporating a universal T-cell epitope (CS.T3) and an immunomodulator (polytuftsin), and delivery through liposomes. Microbiol Immunol 1999, 43:567-576.

71. Pawan K, Ivanov BB, Kabilan L, Rao DN: Construction of a synthetic immunogen: use of the natural immunomodulator polytuftsin in malaria vaccines against RESA antigen of Plasmodium falciparum. Vaccine 1994, $12: 819-824$.

72. Dutta RC, Puri A, Anand N: Immunomodulatory potential of hydrophobic analogs of Rigin and their role in providing protection against Plasmodium berghei infection in mice. Int Immunopharmacol 2001, 1:843-855

73. Khan MA, Aljarbou A, Khan A, Owais M: Immune stimulating and therapeutic potential of tuftsin-incorporated nystatin liposomes against Cryptococcus neoformans in leukopenic BALB/C mice. FEMS Immunol Med Microbiol 2012, 66:88-97.

74. Shakya N, Sane SA, Haq W, Gupta S: Augmentation of antileishmanial efficacy of miltefosine in combination with tuftsin against experimental visceral leishmaniasis. Parasitol Res 2012, 111:563-570.

75. Wardowska A, Dzierzbicka K, Szarynska M, Dabrowska-Szponar M, Wisniewska K, Mysliwski A, Trzonkowski P: Analogues of muramyl dipeptide (MDP) and tuftsin limit infection and inflammation in murine model of sepsis. Vaccine 2009, 27:369-374.

76. Qari MH, Zaki WA: Flow cytometric assessment of leukocyte function in sickle cell anemia. Hemoglobin 2011, 35:367-381.

77. Hanscheid T, Egan TJ, Grobusch MP: Haemozoin: from melatonin pigment to drug target, diagnostic tool, and immune modulator. Lancet Infect Dis 2007, 7:675-685.

78. Kaye D, Gill FA, Hook EW: Factors influencing host resistance to Salmonella infections: the effects of hemolysis and erythrophagocytosis. Am J Med Sci 1967, 254:205-215.

79. Kraal G: Antigens take the shuttle. Nat Immunol 2008, 9:11-12.

80. Morente M, Piris MA, Orradre $J$, Rivas C, Villuendas R: Human tonsil intraepithelial B cells: a marginal zone-related subpopulation. J Clin Pathol 1992, 45:668-672

81. Cinamon G, Zachariah MA, Lam OM, Foss FW Jr, Cyster JG: Follicular shuttling of marginal zone B cells facilitates antigen transport. Nat Immunol 2008, 9:54-62.

82. Chan AC, Leeansyah E, Cochrane A, d'Udekem d'Acoz Y, Mittag D, Harrison LC, Godfrey DI, Berzins SP: Ex-vivo analysis of human natural killer T cells demonstrates heterogeneity between tissues and within established CD4(+) and CD4(-) subsets. Clin Exp Immunol 2013, 172:129-137.

83. Stevenson MM, Kraal G: Histological changes in the spleen and liver of C57BL/6 and A/J mice during Plasmodium chabaudi AS infection. Exp Mol Pathol 1989, 51:80-95.

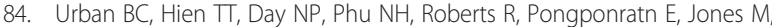
Mai NT, Bethell D, Turner GD, Ferguson D, White NJ, Roberts DJ: Fatal Plasmodium falciparum malaria causes specific patterns of splenic architectural disorganization. Infect Immun 2005, 73:1986-1994.

85. Bockstal V, Geurts N, Magez S: Acute disruption of bone marrow b lymphopoiesis and apoptosis of transitional and marginal zone b cells in the spleen following a blood-stage Plasmodium chabaudi infection in mice. J Parasitol Res 2011, 2011:534697.

86. Sanchez-Torres L, Rodriguez-Ropon A, Aguilar-Medina M, Favila-Castillo L: Mouse splenic CD4+ and CD8+ T cells undergo extensive apoptosis during a Plasmodium chabaudi chabaudi AS infection. Parasite Immunol 2001, 23:617-626.

87. Kapoor G, Bagai U, Banyal HS: Plasmodium berghei induces apoptotic changes in splenic and peripheral blood cells. Trop Biomed 2011, 28:119-124.

88. Dkhil MA: Apoptotic changes induced in mice splenic tissue due to malaria infection. J Microbiol Immunol Infect 2009, 42:13-18.

89. Sponaas AM, Cadman ET, Voisine C, Harrison V, Boonstra A, O'Garra A, Langhorne J: Malaria infection changes the ability of splenic dendritic 
cell populations to stimulate antigen-specific T cells. J Exp Med 2006, 203:1427-1433.

90. Gozzelino R, Soares MP: Heme sensitization to TNF-mediated programmed cell death. Adv Exp Med Bio/ 2011, 691:211-219.

91. Asito AS, Piriou E, Jura WG, Ouma C, Odada PS, Ogola S, Fiore N, Rochford $R$ : Suppression of circulating IgD + CD27+ memory B cells in infants living in a malaria-endemic region of Kenya. Malar J 2011, 10:362.

92. Sullivan RT, Ssewanyana Ssewanyana I, Wamala Wamala S, Ebusu C, Nankya F, Riley EM, Mayanja H, Drakeley C, Kakuru Muhindo M, Arinaitwe E, Tappero J, Kaharuza F, Dorsey G, Greenhouse B: Detailed Kinetics of B Cell Subsets Following Symptomatic Malaria in Children in Tororo, Uganda. In American Society of Tropical Medicine and Hygiene, 62nd Annual Meeting. Abstract 1121. Washington, DC, USA: 2013.

93. Wykes MN, Zhou YH, Liu XQ, Good MF: Plasmodium yoelii can ablate vaccine-induced long-term protection in mice. J Immunol 2005 175:2510-2516.

94. Reynaud CA, Descatoire M, Dogan I, Huetz F, Weller S, Weill JC: IgM memory B cells: a mouse/human paradox. Cell Mol Life Sci 2012, 69:1625-1634.

95. Gondwe EN, Molyneux ME, Goodall M, Graham SM, Mastroeni P, Drayson MT, MacLennan CA: Importance of antibody and complement for oxidative burst and killing of invasive nontyphoidal Salmonella by blood cells in Africans. Proc Natl Acad Sci U S A 2010, 107:3070-3075.

96. MacLennan CA, Gondwe EN, Msefula CL, Kingsley RA, Thomson NR, White SA, Goodall M, Pickard DJ, Graham SM, Dougan G, Hart CA, Molyneux ME, Drayson MT: The neglected role of antibody in protection against bacteremia caused by nontyphoidal strains of Salmonella in African children. J Clin Invest 2008, 118:1553-1562.

97. Eguchi M, Kikuchi Y: Binding of Salmonella-specific antibody facilitates specific T cell responses via augmentation of bacterial uptake and induction of apoptosis in macrophages. J Infect Dis 2010, 201:62-70.

98. Cunningham AF, Gaspal F, Serre K, Mohr E, Henderson IR, Scott-Tucker A, Kenny SM, Khan M, Toellner KM, Lane PJ, MacLennan IC: Salmonella induces a switched antibody response without germinal centers that impedes the extracellular spread of infection. J Immunol 2007, 178:6200-6207.

99. Buffet PA, Safeukui I, Milon G, Mercereau-Puijalon O, David PH: Retention of erythrocytes in the spleen: a double-edged process in human malaria. Curr Opin Hematol 2009, 16:157-164.

100. Kotlyar S, Nteziyaremye J, Olupot-Olupot P, Akech SO, Moore CL, Maitland K: Spleen volume and clinical disease manifestations of severe Plasmodium falciparum malaria in African children. Trans R Soc Trop Med Hyg 2014, 108:283-289.

101. Waitumbi JN, Donvito B, Kisserli A, Cohen JH, Stoute JA: Age-related changes in red blood cell complement regulatory proteins and susceptibility to severe malaria. J Infect Dis 2004, 190:1183-1191.

102. Looareesuwan S, Ho M, Wattanagoon Y, White NJ, Warrell DA, Bunnag D, Harinasuta T, Wyler DJ: Dynamic alteration in splenic function during acute falciparum malaria. N Engl J Med 1987, 317:675-679.

103. Were T, Davenport GC, Hittner JB, Ouma C, Vulule JM, Ong'echa JM, Perkins DJ: Bacteremia in Kenyan children presenting with malaria. J Clin Microbiol 2011, 49:671-676.

104. Biggs HM, Lester R, Nadjm B, Mtove G, Todd JE, Kinabo GD, Philemon R, Amos B, Morrissey AB, Reyburn H, Crump JA: Invasive Salmonella infections in areas of high and low malaria transmission intensity in Tanzania. Clin Infect Dis 2014, 58:638-647.

105. Stoute JA: Complement receptor 1 and malaria. Cell Microbio/ 2011, 13:1441-1450

106. Thomas BN, Diallo DA, Noumsi GT, Moulds JM: Circulating immune complex levels are associated with disease severity and seasonality in children with malaria from Mali. Biomark Insights 2012, 7:81-86.

107. Odhiambo CO, Otieno W, Adhiambo C, Odera MM, Stoute JA: Increased deposition of $\mathrm{C} 3 \mathrm{~b}$ on red cells with low CR1 and CD55 in a malariaendemic region of western Kenya: implications for the development of severe anemia. BMC Med 2008, 6:23.

108. Kai OK, Roberts DJ: The pathophysiology of malarial anaemia: where have all the red cells gone? BMC Med 2008, 6:24.

109. Yadava A, Kumar S, Dvorak JA, Milon G, Miller LH: Trafficking of Plasmodium chabaudi adami-infected erythrocytes within the mouse spleen. Proc Natl Acad Sci U S A 1996, 93:4595-4599.

110. Kirby AC, Beattie L, Maroof A, van Rooijen N, Kaye PM: SIGNR1-negative red pulp macrophages protect against acute streptococcal sepsis after
Leishmania donovani-induced loss of marginal zone macrophages. Am J Pathol 2009, 175:1107-1115.

111. Mollison PL: The reticulo-endothelial system and red cell destruction. Proc R Soc Med 1962, 55:915-920.

112. Kariuki S, Revathi G, Kariuki N, Kiiru J, Mwituria J, Muyodi J, Githinji JW, Kagendo D, Munyalo A, Hart CA: Invasive multidrug-resistant nontyphoidal Salmonella infections in Africa: zoonotic or anthroponotic transmission? J Med Microbiol 2006, 55:585-591.

113. de Jong HK, Parry CM, van der Poll T, Wiersinga WJ: Host-pathogen interaction in invasive salmonellosis. PLoS Pathog 2012, 8:e1002933.

114. Roux CM, Butler BP, Chau JY, Paixao TA, Cheung KW, Santos RL, Luckhart S, Tsolis RM: Both hemolytic anemia and malaria parasite-specific factors increase susceptibility to nontyphoidal Salmonella enterica serovar typhimurium infection in mice. Infect Immun 2010, 78:1520-1527.

115. Mendes J, Goncalves M, Pita-Groz J, Leal MJ: Torsion of the spleen. Chir Pediatr 1988, 29:291-292.

116. Hart AL, Ng SC, Mann E, Al-Hassi HO, Bernardo D, Knight SC: Homing of immune cells: role in homeostasis and intestinal inflammation. Inflamm Bowel Dis 2010, 16:1969-1977.

117. Mora JR, von Andrian UH: Differentiation and homing of IgA-secreting cells. Mucosal Immunol 2008, 1:96-109.

118. Peterson LW, Artis D: Intestinal epithelial cells: regulators of barrier function and immune homeostasis. Nat Rev Immunol 2014, 14:141-153.

119. Liu X, Li Y, Wang Y, Wang Q, Li X, Bi Y, Liu L, Wei X, Li T, Chen J: Gestational vitamin $A$ deficiency reduces the intestinal immune response by decreasing the number of immune cells in rat offspring. Nutrition 2014, 30:350-357.

120. van de Pavert SA, Ferreira M, Domingues RG, Ribeiro H, Molenaar R, Moreira-Santos L, Almeida FF, Ibiza S, Barbosa I, Goverse G, Labao-Almeida C, Godinho-Silva C, Konijn T, Schooneman D, O'Toole T, Mizee MR, Habani Y, Haak E, Santori FR, Littman DR, Schulte-Merker S, Dzierzak E, Simas JP, Mebius RE, Veiga-Fernandes $\mathrm{H}$ : Maternal retinoids control type 3 innate lymphoid cells and set the offspring immunity. Nature 2014, 508:123-127.

121. Owusu-Agyei S, Newton S, Mahama E, Febir LG, Ali M, Adjei K, Tchum K, Alhassan L, Moleah T, Tanumihardjo SA: Impact of vitamin A with zinc supplementation on malaria morbidity in Ghana. Nutr J 2013, 12:131.

122. Semba RD: Vitamin A and immunity to viral, bacterial and protozoan infections. Proc Nutr Soc 1999, 58:719-727.

123. Mawson AR: The pathogenesis of malaria: a new perspective. Pathog Global Health 2013, 107:122-129.

124. Hussein MM, Mooij JM, Roujouleh HM, Hamour OA, Felemban H: Nontyphoid Salmonella septicemia and visceral leishmaniasis in a renal transplant patient. Transplantation 2001, 71:479-481.

125. Kayserili E, Hizarcioglu M, Gulez P, Apa H, Keskin S: Co-existence of Kala-azar and salmonellosis in a 16 month-old baby? Or a false positive widal reaction in Kala-azar?(in Turkish). Turkiye Parazitol Derg 2005, 29:141-144.

126. Carvalho EM, Bacellar O, Barral A, Badaro R, Johnson WD Jr: Antigen-specific immunosuppression in visceral leishmaniasis is cell mediated. J Clin Invest 1989, 83:860-864.

127. Gendrel D, Kombila M, Beaudoin-Leblevec G, Richard-Lenoble D: Nontyphoida salmonellal septicemia in Gabonese children infected with Schistosoma intercalatum. Clin Infect Dis 1994, 18:103-105.

128. Gordon MA, Zijlstra EE, Naus CW, Visser LG, Molyneux ME, van Lieshout L: Schistosomiasis does not contribute to death or recurrence of nontyphoid Salmonella bacteremia in human immunodeficiency virus-infected Malawian adults. Clin Infect Dis 2003, 37:e177-e179.

129. Piyaphanee $W$, Issarachaikul R, Soontarach P, Silachamroon U: Concurrent salmonella bacteremia in $P$. vivax infection-a report of 2 cases at the Hospital for Tropical Diseases, Thailand. Southeast Asian J Trop Med Public Health 2007, 38:616-618.

130. Sur D, von Seidlein L, Manna B, Dutta S, Deb AK, Sarkar BL, Kanungo S, Deen JL, Ali M, Kim DR, Gupta VK, Ochiai RL, Tsuzuki A, Acosta CJ, Clemens JD, Bhattacharya SK: The malaria and typhoid fever burden in the slums of Kolkata, India: data from a prospective community-based study. Trans R Soc Trop Med Hyg 2006, 100:725-733.

131. Keong BC, Sulaiman W: Typhoid and malaria co-infection - an interesting finding in the investigation of a tropical fever. Malays J Med Sci 2006, 13:74-75.

132. Kumar A, Katiyar GP: Mixed infection with Plasmodium-vivax and Salmonella typhi in an infant. Indian Pediatr 1995, 32:243-244. 
133. Shanks GD, White NJ: The activation of vivax malaria hypnozoites by infectious diseases. Lancet Infect Dis 2013, 13:900-906.

134. Bynum B: Typhomalaria. Lancet 2002, 360:1339.

135. Bhattacharya SK, Sur D, Dutta S, Kanungo S, Ochiai RL, Kim DR, Anstey NM, von Seidlein L, Deen J: Vivax malaria and bacteraemia: a prospective study in Kolkata. India Malar J 2013, 12:176.

136. Burger $P$, Hilarius-Stokman $P$, de Korte $D$, van den Berg TK, van Bruggen $R$ : CD47 functions as a molecular switch for erythrocyte phagocytosis. Blood 2012, 119:5512-5521.

137. Liu J, Guo X, Mohandas N, Chasis JA, An X: Membrane remodeling during reticulocyte maturation. Blood 2010, 115:2021-2027.

138. Liu J, Mohandas N, An X: Membrane assembly during erythropoiesis. Curr Opin Hematol 2011, 18:133-138.

139. Zhao XW, van Beek EM, Schornagel K, Van der Maaden H, Van Houdt M, Otten MA, Finetti P, Van Egmond M, Matozaki T, Kraal G, Birnbaum D, van Elsas A, Kuijpers TW, Bertucci F, van den Berg TK: CD47-signal regulatory protein-alpha (SIRPalpha) interactions form a barrier for antibody-mediated tumor cell destruction. Proc Natl Acad Sci U S A 2011, 108:18342-18347.

140. Pinaki Panigrahi SP, Lingaraj P, Nimai N, Radhanath Satpathy DC, Rama C, Pravas M, Hegang, Chen JAJ, Glenn Morris J Jr, Nigel P, Gewolb IH: Effectiveness of a Lactobacillus Plantarum Synbiotic Therapy for Preventing Late Onset Sepsis in Neonates. In 2013 Pediatric Academic Societies Annual Meeting. Abstract 3618.2. Washington DC, USA: 2013.

141. Deshmukh HS, Liu Y, Menkiti OR, Mei J, Dai N, O'Leary CE, Oliver PM, Kolls JK, Weiser JN, Worthen GS: The microbiota regulates neutrophil homeostasis and host resistance to Escherichia coli K1 sepsis in neonatal mice. Nat Med 2014, 20:524-530.

doi:10.1186/1475-2875-13-335

Cite this article as: Gómez-Pérez et al: Plasmodium falciparum malaria and invasive bacterial co-infection in young African children: the dysfunctional spleen hypothesis. Malaria Journal 2014 13:335.

\section{Submit your next manuscript to BioMed Central and take full advantage of:}

- Convenient online submission

- Thorough peer review

- No space constraints or color figure charges

- Immediate publication on acceptance

- Inclusion in PubMed, CAS, Scopus and Google Scholar

- Research which is freely available for redistribution 